\title{
DETAILED FIELD WORK IN TWO OUTCROPS OF THE NAZARÉ PAULISTA ANATECTIC GRANITE, SE BRAZIL
}

\section{VALDECIR DE ASSIS JANASI, LUCELENE MARTINS \& SILVIO R.F. VLACH}

\begin{abstract}
Two exposures of the anatectic Nazaré Paulista garnet-biotite granite and its country rocks were studied in detail in order to identify the different granite bodies and their relations to each other. In outcrop NP74, three main granite bodies and smaller aplitepegmatite layers were distinguished, all intrusive but subconcordant with the country-rock migmatitic (garnet)-biotite gneisses. The first granite body (from NW to SE; 74g 1), $43 \mathrm{~m}$ thick, is made up of veined gray garnet-biotite granite; garnet leucogranite veins form a network cutting the gray granite, and surround the abundant gneiss xenolith and schlieren; the roof zone is a $\sim 8 \mathrm{~m}$ thick garnet leucogranite with abundant xenoliths that can have formed by concentration of the vein-forming material. The $\sim 12 \mathrm{~m}$ thick $74 \mathrm{~g} 2$ body occurs after a thin gneiss septum; it is made up of a garnet leucogranite with local pegmatite patches. The $\sim 20 \mathrm{~m}$ thick $74 \mathrm{~g} 3$ granite forms the southern end of the outcrop, after a large exposure of country rock intruded by pegmatite layers; it is made up of ( \pm biotite)garnet leucogranite with local fibrolite. In outcrop NP40, country-rock migmatites only appear as weathered rocks surrounding the granite exposure. Here, a $15 \mathrm{~m}$ wide body of veined gray granite $(40 \mathrm{~g} 2)$ is intruded in its central portion by a white leucogranite (40g3) possibly formed by collection of differentiated material from the veins, and on both sides by heterogeneous, schlieren-rich aplite-pegmatite garnet leucogranite (40gl and 40g4). These two outcrops reveal that a wide variety of "Nazaré Paulista granite" exists at the detailed scale, forming small bodies that can have their mutual relationships identified. The veined gray granite, usually considered as the "typical" Nazaré Paulista granite, has wide distribution in the region, but is locally subordinated to more leucocratic varieties. The latter can be directly related to the collection of the vein material next to xenoliths or at the roof of the gray granite bodies, but they also form independent bodies which may have a totally different genesis. Structural evidence of syn-magmatic extension in outcrop NP74 suggests that some magma migration occurred in an extending collisional belt; however, the timespan of anatexis in the region may have been large (> $10 \mathrm{Myr}$ ?), and still demands further precise age determinations.
\end{abstract}

Keywords: granite, anatexis, migmatite, field geology, plutonic bodies

Resumo GEOLOGIA DE DETALHE EM DOIS AFLORAMENTOS DO GRANITO ANATÉTICO PAULISTA, SE DO BRASIL Duas exposições complexas do granada-biotita granito anatético Nazaré Paulista e de suas rochas encaixantes foram estudadas para identificar os diferentes corpos de granito e suas relações. No afloramento NP74, três corpos graníticos principais e corpos menores de aplito-pegmatito foram distinguidos, todos intrusivos mas subconcordantes com (granada)-biotita gnaisses migmatíticos encaixantes. O primeiro corpo (de NW para SE; 74g 1), com espessura de $~ 43 \mathrm{~m}$, é composto de granada-biotita granito cinza venulado; veios de granada leucogranito formam uma rede cortanto o granito cinza, e contornam os abundantes xenólitos de gnaisse e schlieren; a zona de teto é formada por $\sim 8 \mathrm{~m}$ de granada leucogranito com abundantes xenólitos, que pode ter se formado por concentração do material presente nos veios. O granito $74 \mathrm{~g} 2$, com espessura de $~ 12 \mathrm{~m}$, ocorre após um estreito septo gnáissico; é constituído por um granada leucogranito com bolsões pegmatíticos locais. O granito $74 \mathrm{~g} 3$, com espessura de $\sim 20 \mathrm{~m}$, forma extremo sul do afloramento, e ocorre após uma grande exposição de rocha encaixante invadida por camadas de pegmatito; é formado por ( \pm biotita)-granada leucogranito com fibrolita local. No afloramento NP40, os migmatitos encaixantes ocorrem apenas como rochas alteradas circundando a exposição de granito. Aqui, um corpo com largura de $\sim 15 \mathrm{~m}$ de granito cinza venulado (40g2) é invadido em sua porção central por um leucogranito branco $(40 \mathrm{~g} 3)$ possivelmente formado pela coleta de material diferenciado das vênulas, e invadido em ambos os lados por um granada leucogranito aplítico-pegmatítico heterogêneo, rico em schlieren (40g 1 e 40g4). Esses dois afloramentos mostram que uma ampla variedade de "granitos Nazaré Paulista" existe mesmo na escala de detalhe, formando pequenos corpos cujas relações mútuas podem ser identificadas. O granito cinza venulado, em geral considerado como o granito Nazaré Paulista "típico", tem distribuição ampla na região, mas é localmente subordinado em relação às variedades mais leucocráticas. Estas podem ser relacionadas diretamente à coleta de material proveniente das vênulas em torno de xenólitos ou no teto dos corpos de granito cinza, mas também formam corpos independentes que podem ter gênese totalmente distinta. Evidências estruturais de extensão sin-magmática no afloramento NP74 sugerem que alguma migração de magma ocorreu em um cinturão colisional extensional; no entanto, o intervalo de tempo em que ocorreu anatexia na região pode ter sido grande (> 10 milhões de anos?), e ainda requer determinações de idade precisas adicionais.

Palavras-chave: granito, anatexia, migmatito, geologia de campo, corpos plutônicos

INTRODUCTION The Nazaré Paulista granite has drawn the attention of geologists for years because of its peculiar structure, texture and mineralogy, all suggestive of an anatectic origin directly linked to the enclosing migmatites. Attempts to map it, however, have revealed frustrating. A nice faciological map of a granite body calls for good outcrops and some petrographic variation that can be rationally registered at the scale of interest (cf. Ulbrich et al. 2001 for details on procedures for granite mapping). A few days exploring the region, using the regional map by Campos Neto et al. (1983) as a guide, showed that, given the scarcity of outcrops and the complexity of the area, the apparently simple task of separating granite and country migmatites was too often speculative even at the more regional scale used in that map $(1: 50,000)$. This is not to say separating different granite facies although they obviously exist, as shown by the diversity of petrographic types seen in every outcrop, and particularly from close examination of the extensive road cut at the Dom Pedro I highway, next to the Nazaré Paulista town, that is visited by everyone wishing to be introduced to this granite.

The complexity of the Nazaré Paulista granite has not 
discouraged scientists from studying it over the years, offering some good contributions on its geology and petrogenesis (e.g., Campos Neto et al. 1983, Wernick et al. 1987, Tassinari 1988, Artur et al. 1993, Ragatky 1998, Janasi 1997, 1999a,b). Most of the results presented in these works come from the same outcrop cited above - and nevertheless the examination of the petrographic descriptions and chemical results show that the rocks under focus are too diverse, and we often have to understand what was meant by "Nazaré Paulista-type granite" in a given publication.

We eventually realized that the best way to understand the Nazaré Paulista granite was mapping this $\sim 350 \mathrm{~m}$ long outcrop at a detailed scale, trying to identify the different bodies and sampling every variety of granite and country-rock migmatite. The results are presented here, along with those of a similar work done on a second good exposure, another road cut $\sim 10 \mathrm{~km}$ northwest from the first. The geological profiles presented here are the basis of a detailed study on the mechanisms and timing of granite generation, extraction and migration on the continental crust, currently undertaken by L. Martins. We think their presentation can be of interest to many people involved in mapping high-grade terranes, so common in Precambrian areas of Brazil, and those working more specifically on granite petrogenesis.

GEOLOGICALSETTING Tectonic setting The type area of the Nazaré Paulista granite is the southernmost portion of the Socorro-Guaxupé Nappe (SGN), an allochthonous terrane thrust eastwards over the southern São Francisco Craton (Campos Neto \& Caby 2000). The SGN is part of a nappe system that resulted from the convergence between the São Francisco and Paranapanema plates at the end of the Neoproterozoic (Campos Neto \& Caby 1999). In contrast with the neighbor nappes, it is characterized by the occurrence of abundant granites and high temperature metamorphism, achieving granulite facies in its basalmost portions. Campos Neto (2000) interprets it as a continental arc terrane developed at the margin of the Paranapanema plate slightly before continental collision.

The SGN is exposed as two main segments, both as SW-dipping homoclinals disturbed by late NE-SW faulting and folding. The southern segment, referred to as "Socorro Domain", exposes a $\sim 20 \mathrm{~km}$ crust section, with thin layers of mafic granulite crystallized at $\mathrm{P} \sim 11 \mathrm{kbar}$ and $850^{\circ} \mathrm{C}$ in the north (Freitas 2000) succeeded by migmatitic orthogneisses and an upper metasupracrustal unit metamorphosed at 5 kbar (Vasconcellos et al. 1991, M.C. Campos Neto pers. comm., 2003) that dominates the southernmost portion and hosts the Nazaré Paulista granites.

Local geology Figure 1 is a compilation of geological maps of the Atibaia-Piracaia-Nazaré Paulista region presented at the 1:50,000 scale (Campos Neto et al. 1983, Oliveira et al. 1985, Janasi 1986, Melhem 1995), modified by the authors. Several granitic (s.l.) occurrences, formed by a wide variety of rocks, all with Neoproterozoic ages, intrude the metamorphic rocks ascribed to the Piracaia Complex.

A stratigraphic column was proposed for the Piracaia Complex by Campos Neto et al. (1983): the basal unit is made up of migmatitic biotite gneiss (tonalitic to granitic) of unknown affinity (orthogneiss?) that occurs mostly in the region of Piracaia (Figure 1). Above it, appears a thick garnet-biotite gneiss unit (also strongly migmatized) with calc-silicate and amphibolite decimetersized layers, interpreted as derived from metagraywackes (Janasi, 1999a). The upper unit is dominated by metapelite (sillimanitegarnet-biotite schist), with minor quartz schist and quartzite.

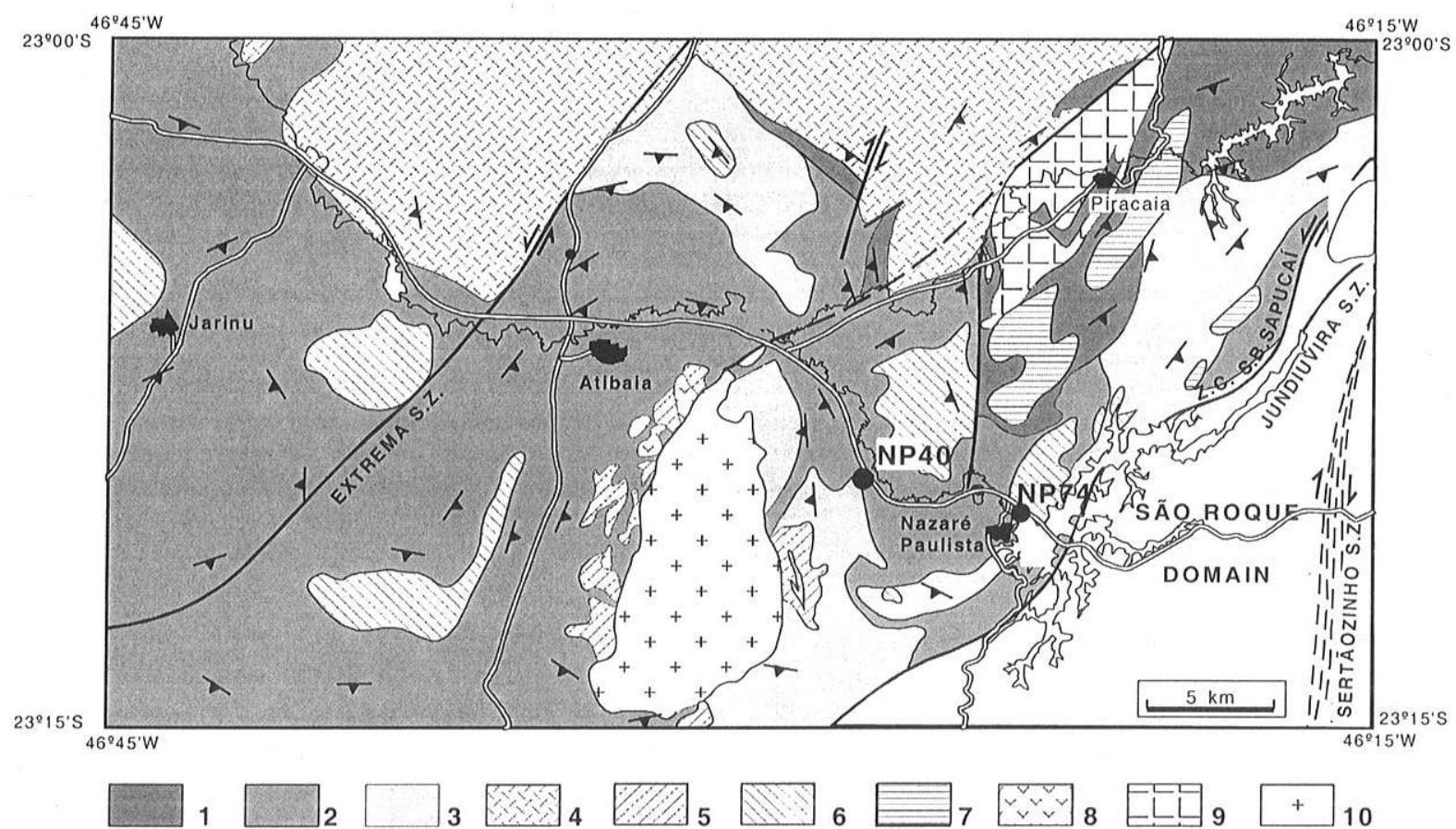

Figure 1 - Geological sketch map of the Atibaia-Piracaia-Nazaré Paulista region, with emphasis on granite bodies. Compiled by the authors from Campos Neto et al. (1983), Oliveira et al. (1985), Janasi (1986) and Melhem (1995). 1, 2, 3 = Piracaia Metamorphic Complex (1=Bt gneiss; $2=$ Grt-Bt gneiss; $3=($ Sil $)-$ Grt-Bt-schist $) ; 4=$ high-K calc-alkaline granite; $5=M s-B t$ leucogranite $; 6=$ Nazaré Paulista Grt-Bt granite; 7 = Quatro Cantos Bt granite; $8=$ Porphyritic tonalite-granodiorite $; 9=$ Piracaia monzodiorite $; 10$ = Atibaia granite. 
Recent $\mathrm{U}-\mathrm{Pb}$ zircon and monazite dating revealed that the Brasiliano granite magmatism extended at least from $\sim 640 \mathrm{Ma}$ (orthopyroxene-bearing calc-alkaline granodiorites; Hackspacher et al., 2003) to $\sim 570 \mathrm{Ma}$ (Piracaia monzodiorite, V.A. Janasi, unpublished data). The most voluminous occurrences are made up of high-K calc-alkaline granite (dominantly porphyritic hornblende-biotite monzogranite) from the Socorro Batholith, dated at $630 \mathrm{Ma}$ (Topfner, 1996).

Most of the small bodies shown in the map are heterogeneous anatectic granites closely related to the Nazaré Paulista granites. On the basis of their mineralogy, they are divided into three main types: white muscovite-biotite granite (mostly surrounding the Atibaia granite); gray or pink garnet-biotite granite (known collectively as the Nazaré Paulista-type granites); and (usually) pink biotite granite (mostly intrusive into the basal unit of the Piracaia Complex, and known as the Quatro Cantos-type granites). Janasi (1999b) presented monazite U-Pb data for the first two types, concluding for ages of $\sim 620-625 \mathrm{Ma}$.

The Atibaia granite is a younger intrusion intruding the anatectic granites, as yet imprecisely dated (a $~ 590 \mathrm{Ma} \mathrm{Rb-Sr}$ isochron presented by Melhem, 1995), and made up of red syenogranite with some A-type affinities.

The Nazaré Paulista granite The Nazaré Paulista granite was first distinguished as a separated body by Campos Neto et al. (1983); these authors mapped a main core of more homogeneous nebulitic garnet-biotite granite as a more or less circular body located NW from the Nazaré Paulista city, with 4-5 km diameter and $14 \mathrm{~km}^{2}$ area, surrounded by a $0.5-3 \mathrm{~km}$ migmatite envelope. Oliveira et al. (1985) mapped other anatectic granite bodies that were correlated to the Nazaré Paulista granite in the contiguous Atibaia region. Other petrographic types were described under the same name, many of them, such as white muscovite-biotite granites and biotite granites, lacking the characteristic garnet-rich spots.

Wernick et al. (1987) did a zircon typology study on the Nazaré Paulista granites, concluding for a crustal origin, and inferring higher crystallization temperatures for grey monzogranite to granodiorites $\left(720-680^{\circ} \mathrm{C}\right)$ as compared to a white syenogranite $\left(\sim 660^{\circ} \mathrm{C}\right)$. Tassinari $(1988)$ obtained $\mathrm{Pb}-\mathrm{Pb}$ data on whole-rock and feldspars from the Nazaré Paulista granite; the relatively high ${ }^{207} \mathrm{~Pb} /$ ${ }^{204} \mathrm{~Pb}$ values were interpreted to reflect sources in the upper continental crust. Ragatky (1998) showed that samples of the Nazaré Paulista granite had more negative eNd(t) than the country paragneisses, and discarded the latter as the source of the granite magma; a tonalitic gneiss from neighbor outcrops was considered as the more probable source.

Janasi (1997) studied the three main types of crust-derived granites found in different levels of the Socorro-Guaxupé Nappe. The Nazaré Paulista-type granites, separated into gray granites and white leucogranites, were interpreted as products of muscovite breakdown $\left(\sim 50^{\circ} \mathrm{C}\right)$, derived from biotite-rich sources (with an important metapelite component).

Janasi (1999a,b) obtained a $625 \pm 4 \mathrm{Ma} U-\mathrm{Pb}$ monazite age for a veined gray granite from outcrop NP40 (see below), interpreted as the crystallization age of the Nazaré Paulista granite. On the basis of geochemistry and Sr-Nd isotopy, a genetic model was put forward in which the gray NP granite was interpreted as a product

A stratigraphic column was proposed for the Piracaia Complex by Campos Neto et al. (1983): the basal unit is made up of migmatitic biotite gneiss (tonalitic to granitic) of unknown affinity (orthogneiss?) that occurs mostly in the region of Piracaia (Figure 1). Above it, appears a thick garnet-biotite gneiss unit (also of melting of mixed sources which included immature metasedimentary rocks similar to the country garnet-biotite gneisses and a component with low $\mathrm{Rb} / \mathrm{Sr}$ and more negative $\varepsilon \mathrm{Nd}_{\mathrm{T}}$ tentatively interpreted as unexposed basement sequences. Other anatectic granites could be derived from single sources (e.g., muscovitebiotite granites derive from the metasedimentary sequences, and biotite granites from LREE and Sr-rich orthogneisses).

Vlach \& Gualda (2000) did a monazite chemical dating with the electron microprobe in a veined granite from outcrop NP74 (see below), and obtained a $614 \pm 14 \mathrm{Ma}$ age. Although this is within error of the age reported by Janasi (1999b), other ages recently obtained in samples from outcrop NP74 are clearly younger: A. Fetter (pers. comm., 2003) dated a monazite from a granitic leucosome with conventional U-Pb TIMS at $608 \pm 1 \mathrm{Ma}$, and Ragatky (1998) obtained a $610 \pm 8$ Ma whole rock-garnet (twopoint) $\mathrm{Sm}-\mathrm{Nd}$ isochronic age for a leucogranite. These results point to the possibility that anatexis occurred over a time interval of up to 15 Myr. in the Nazaré Paulista region.

\section{DETAILED GEOLOGICAL SURVEY Outcrop NP74 Outcrop} NP 74 is a roadcut located at km 51-52 of the D. Pedro I highway, next to the Nazaré Paulista city, consisting of an almost continuous $\sim 360$ m exposure of garnet-biotite granites and migmatites.

Figure 2 is a simplified geological profile drawn from a detailed field investigation and digital photographs. Distances signalled in Fig. 2 were measured on the terrane and refer to an arbitrary origin set on the first continuous exposures of fresh rock in the NW extremity of the roadcut. Granites and migmatitic gneisses alternate with each other throughout the profile, and make up more or less equivalent proportions of the exposure. Also signalled in Fig. 2 are the sites of sampling for petrography.

The gneissic rocks show foliation and metamorphic layering running N30-50E, with moderade to strong (40-75 $)$ dips to SE. Granite and pegmatite bodies are usually subconcordant but are often seen to cut the gneiss foliation. These intrusive bodies have varied dimensions, and are intercalated with the migmatitic gneisses along the exposure; however; three major granite bodies, here named $74 \mathrm{~g} 1$ to $74 \mathrm{~g} 3$, can be distinguished.

The exposure begins, in the NW, with garnet-biotite gneisses with very local sillimanite, intruded by small pegmatite bodies.

The first main granite body (74g1) appears after c. $10 \mathrm{~m}$ (Fig. 2 ), and extends for $\sim 74 \mathrm{~m}$ in the terrane. The variety is that known by most geologists as the "typical" Nazaré Paulista granite: a gray equigranular garnet-biotite granite $\left(\mathrm{M}^{\prime}=5-7\right)$ densely veined by a white medium to coarse-grained garnet leucogranite (Fig. 3a). Both gray granite and veins have low magnetic susceptibility $(K<0.1 \mathrm{x}$ $\left.10^{-3} \mathrm{SI}\right)$. This body hosts several garnet-biotite gneiss xenoliths (cf. Fig. 3e), the largest reaching a few meters (cf. occurrences shown in the profile at $\sim 30 \mathrm{~m}$ and $48 \mathrm{~m}$ ) and the smallest grading to biotite-rich schlieren. Most contacts with the xenoliths are delineated by aplite or pegmatite bodies that are petrographically similar to the veins which crosscut the gray granite (Fig. 3f). At $\sim 85 \mathrm{~m}$ the veined gray granite gives way to a leucogranite $(\mathrm{IC}<4)$ with aplitic (sacaroidal) texture, in some places showing thin layers rich in idiomorphic reddish garnet (Fig. 3b). The contact is subconcordant and diffuse; the leucogranite hosts at least three main concordant dm-sized gneiss lenses in this portion (Fig. 2), and is followed, from 113 to $120 \mathrm{~m}$, by a larger septum dominated by banded biotite-plagioclase gneiss (samples NP74O and NP74Q; 
Detailed field work in two outcrops of the Nazaré Paulista anatectic granite, Se Brazil

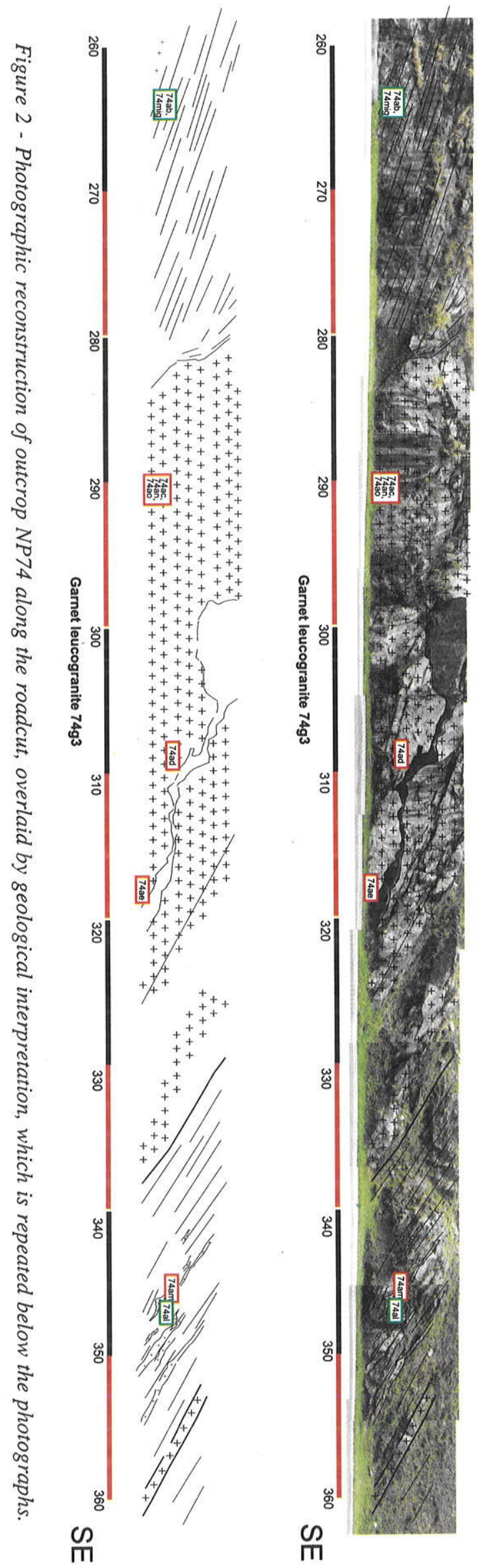

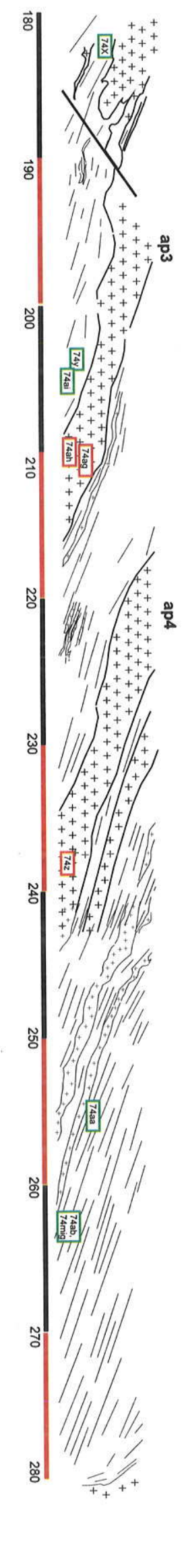

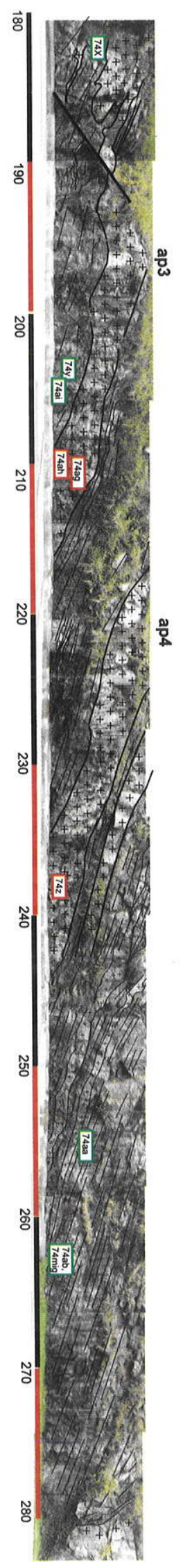

Revista Brasileira de Geociências, Volume 35, 2005 
Valdecir de Assis Janasi et al.
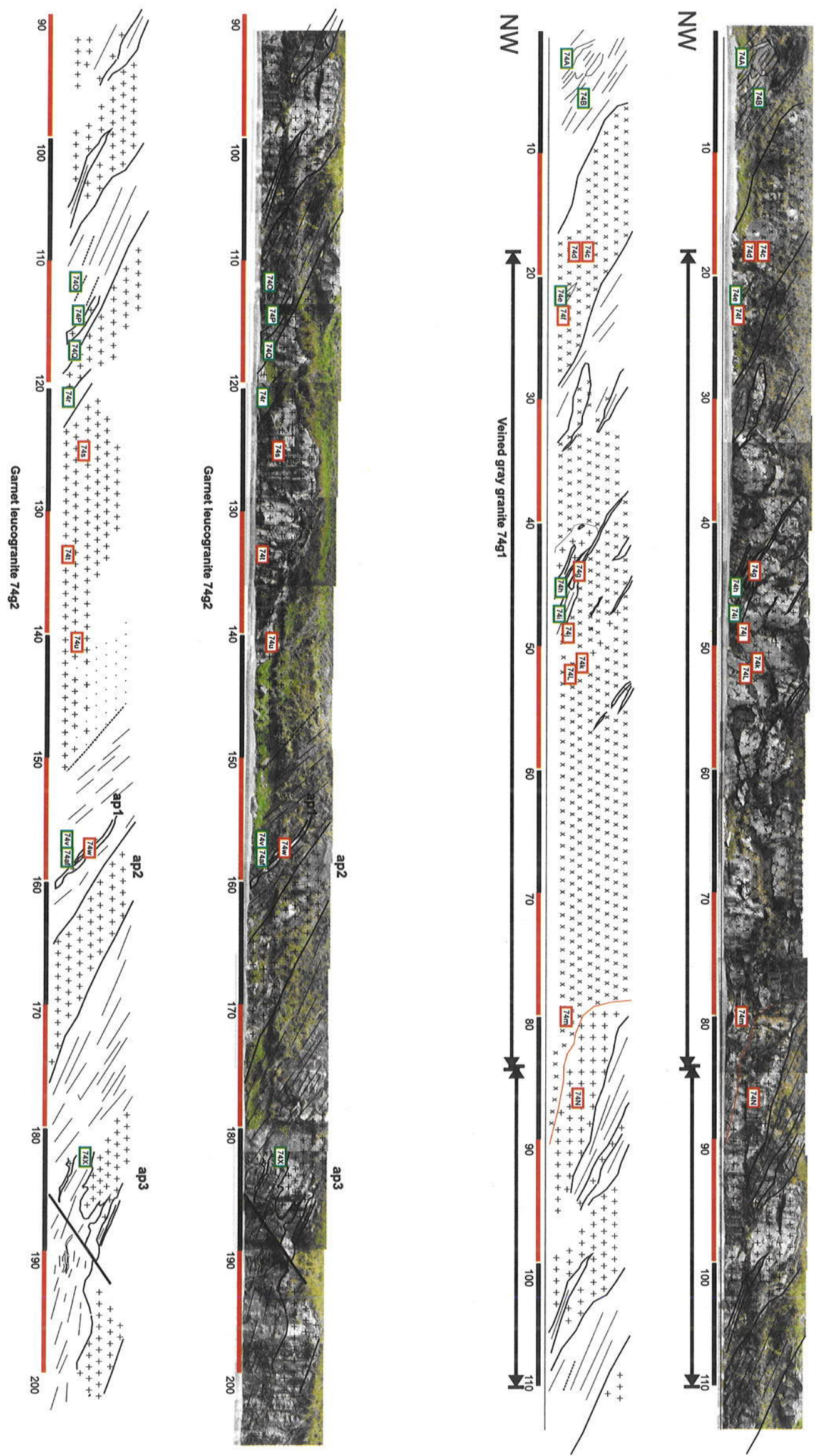
garnet-biotite gneiss -NP7R- is subordinate). Our preferred interpretation for this leucogranite is that it is a roof facies of the gray granite $74 \mathrm{~g} 1$ body, corresponding to a major concentration of the felsic material that fills up the veins around large country rock inclusions. Taking into consideration the average contact dips, the 74g1 body has an estimated thickness of $\sim 50 \mathrm{~m}$, the upper $10 \mathrm{~m}$ corresponding to the leucocratic roof facies and gneiss inclusions.

The new granite body appearing after $120 \mathrm{~m}$ (Fig. 2) is a $<20 \mathrm{~m}$ large aplitic garnet leucogranite (Fig. 3c) that bears muscovitebearing pegmatite patches towards its upper contact. This rock resembles the upper portion of $\mathbf{7 4 g} \mathbf{1}$, but is interpreted as a separate intrusion $(74 \mathrm{~g} 2)$ from which three samples were collected (NP74S, $\mathrm{T}, \mathrm{U})$.

An extensive exposure of migmatitic gneisses occupies the whole central portion of the roadcut (from 150 to $280 \mathrm{~m}$; estimated thickness, $65 \mathrm{~m}$ ). Their dips are strongest in the first meters, apparently as a refletion of the intrusion of granite $74 \mathrm{~g} 2$ (Fig. 2).
These gneisses are intruded by several subconcordant pegmatite bodies; the largest ones, with thickness varying from 1 to $5 \mathrm{~m}$, were identified and numbered in Fig. 2 (apl, 2 etc, where ap= aplite/pegmatite). The two main pegmatite bodies (ap3, ap4), both with $\sim 5 \mathrm{~m}$ thickness and sattelite bodies $\sim 1 \mathrm{~m}$ thick injected above them, crop out in the 200 to $250 \mathrm{~m}$ interval, and were sampled (samples NP74AH/AG and NP74Z; cf. Fig. 2, Fig. 3g).

Several gneiss samples were collected from this central portion of the profile. SE from ap4 (between 245 and 275 m) they are coarsegrained garnet-biotite-gneisses with "granitic" (K-feldspar-rich) composition (samples NP74AA and AB; cf. Fig. 3h). From 150 to at least $180 \mathrm{~m}$, however, garnet-free gneisses are common (e.g., NP74V, surrounding ap1, a biotite pegmatite), and small amphibolite and calc-silicate rock intercalations, forming $\mathrm{dm}$-sized boudins, occur locally (e.g., sample NP74AF).

Between 180 and $200 \mathrm{~m}$, a normal fault with $\sim 20-50 \mathrm{~cm}$ offset is observed; the structure is revealed by the displacement of aplite body ap3 and its satellite vein along a fracture zone (Fig. 2) which
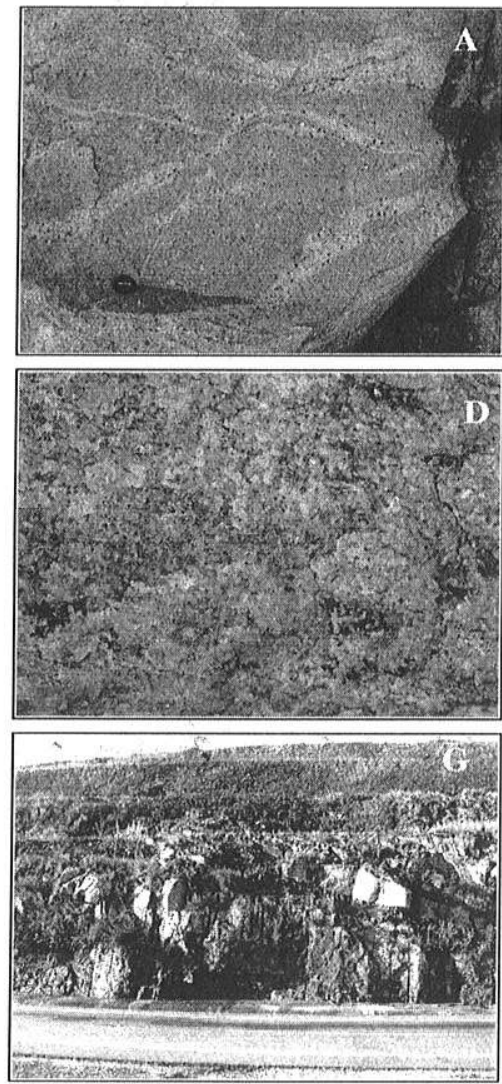
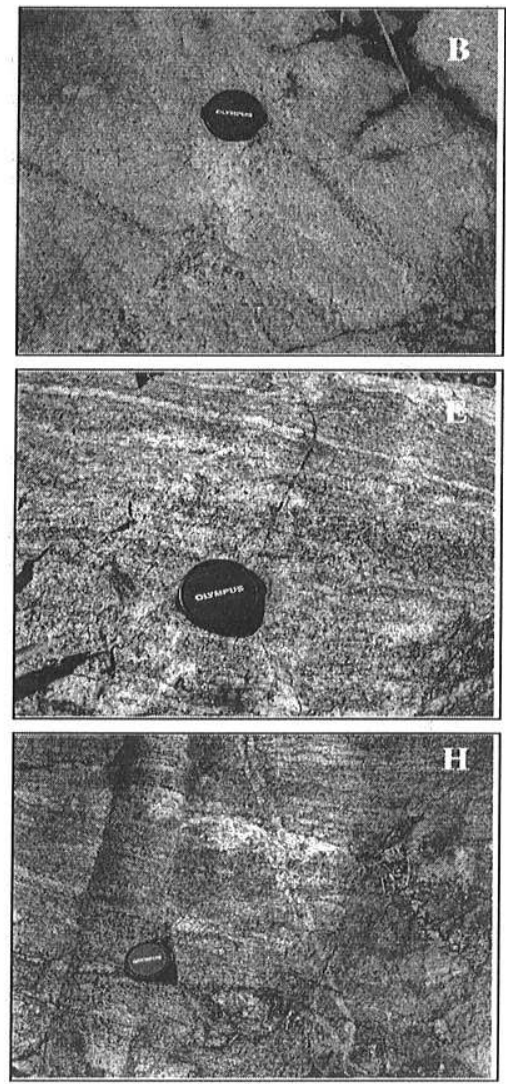
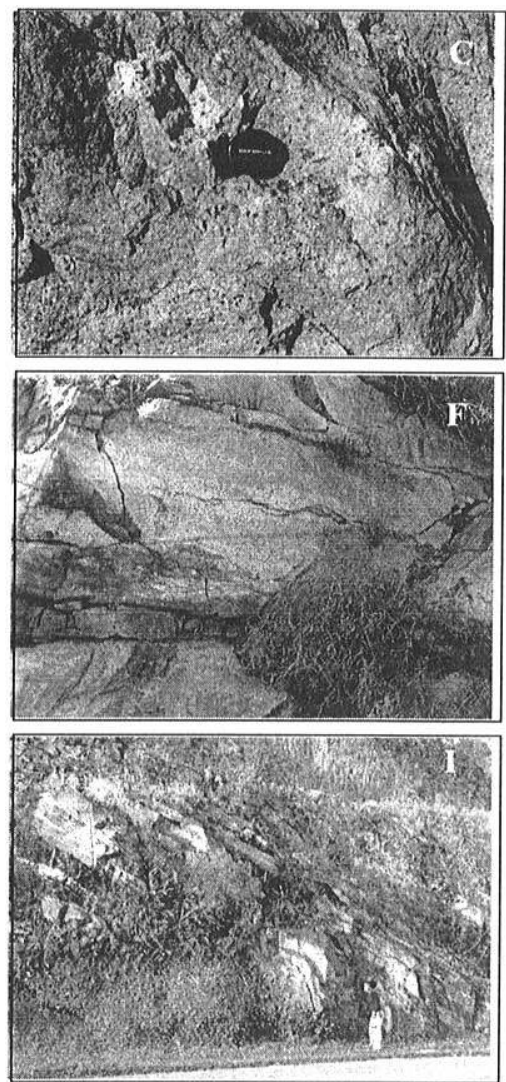

Figure 3. Field photographs of the Nazaré Paulista granite and country rocks in outcrop NP74. a) Veined gray garnet-biotite granite; white leucogranite veins cutting the gray granite are mostly rectilinear (at $50 \mathrm{~m}$ in Figure 2); b) Garnet leucogranite from the roof of $74 \mathrm{gl}$ showing a layer rich in idiomorphic garnet affected by an extensional fault filled with coarser granite, at $89 \mathrm{~m} ; \mathrm{c}$ ) Garnet aplite-pegmatite from $74 \mathrm{~g} 2$, equivalent to sample $\mathrm{NP} 74 \mathrm{t}$, at $\sim 134 \mathrm{~m} ;$ d) Garnet leucogranite typical of $74 \mathrm{~g} 3 ;$ thin fibrolite films parallel to foliation (dipping slightly to the right of the photo) occur in this portion, but are difficult to see because of white color; $315 \mathrm{~m}$; e) Structure of garnet-biotite gneiss found as xenoliths within 74g 1 ; equivalent to sample NP74i, $48 \mathrm{~m}$; f) Biotite-rich schlieren sided by concentration of light granite (vein material) within the gray granite (74g1) body, at $\sim 65 \mathrm{~m}$; g) Concordant pegmatite body ap3 with satellite $~ 1 \mathrm{~m}$-wide pair above; site of sample NP74aj, at $230 \mathrm{~m} ; \mathrm{h}$ ) Structure of the migmatitic garnetbiotite gneiss at $267 \mathrm{~m}$ (equivalent to sample NP74ab); note stromatic aspect, with thin melanosome bordering some leucosomes. A late vein cuts the migmatite layering; i) Injection migmatite with biotite gneiss "mesossome" and biotite granite layers with thicknesses varying from $\mathrm{cm}$ to $\mathrm{dm} ; 350 \mathrm{~m}$. 
has a thin $(1-2 \mathrm{~cm})$ portion of protomylonite. Smaller associated normal faults are observed in this portion of the outcrop; some are filled with granite, showing the extension to have been synmagmatic.

The contact of the third major granite body (74g3) with the gneisses is subconcordant, but in detail the gneiss layering is seen to be truncated, and large biotite crystals are seen growing from the contact towards the granite. This body extends for c. 50 $\mathrm{m}$ (estimated thickness, $25 \mathrm{~m}$ ), and is made up of a white garnet leucogranite (Fig. 3d) with portions of a grayish granite showing diffuse banding subparallel to the contacts. Locally, this granite shows thin films of fibrolite, in part replaced by muscovite.

In this portion of the outcrop, a late pink biotite granite occurs as a $10-20 \mathrm{~cm}$-wide dike cutting the garnet leucogranite. The dike was strongly affected by syn-magmatic shearing; as a result, the granite in its borders is mylonitic, and has a dark color, which is apparent in its walls as seen in the profile at $\sim 300-320$ m (Fig. 2).

The final portion of the exposure is made up of banded darkgray biotite gneisses that have the aspect of injection migmatites (Fig. 3i). The gneiss itself is homogeneous and looks like a deformed dark-gray granite; it is nearly garnet-free, the same occurring in the leucosomes. Although usually surrounded by biotite-rich melanosomes, most of the leucosomes appear to be too thick (10$30 \mathrm{~cm}$ ) to be derived by in situ segregation from the adjacent gneiss. Garnet-biotite gneisses reappear after the 330 m mark, as boulders immerse in soil material, and locally bear a thin layer of garnet-bearing metabasic rock.

Outcrop NP40 Outcrop NP40 is another roadcut in the D. Pedro I highway, located $\sim 10 \mathrm{~km}$ NW from NP74, next to Bom Jesus dos Perdões (Fig. 1). It consists of two parallel exposures, one at a lower level, adjacent to the highway (96 $\mathrm{m}$ wide, $<1$ to $3 \mathrm{~m}$ high), and the upper at a highway exit. A varied set of veined gray garnetbiotite granites and white garnet leucogranites similar to those described in outcrop NP74 is exposed. The contacts between the different lithologies are shown in the two profiles of Figure 4, drawn from detailed study and digital photographs. Figure 4a shows the geology of the lower exposure; the geology of the upper exposure is shown in Figure 4b.

Both exposures are made up essentially of granites, but this is a very small ocurrence, not represented in regional geologic maps at the 1:50,000 scale (e.g., Campos Neto et al. 1983); as shown by examination of neighbor weathered rock, it is totally surrounded by migmatitic gneisses. A small portion of fresh garnet-biotite gneiss occurs above the granite at the northern extremity of the upper exposure (Fig. 4b).

The granites show foliation, layering and mutual contacts nearly orthogonal to the exposure ( N10E, dipping 50-60 $\mathrm{NW}$ ), subconcordant with the foliation of the nearby gneisses. Integration of the two detailed profiles allowed the identification of four main granite bodies.

Veined gray granite occurs in the central portion of the lower cut (between 29 and $66 \mathrm{~m}$; estimated thickness, $20 \mathrm{~m}$ ) and in the beginning of the upper cut (from 5 to $42 \mathrm{~m}$; estimated thickness, 25 $\mathrm{m}$ ). This body, here named $40 \mathrm{~g} 2$, is made up of a gray granite that resembles 74g1, but is finer-grained and lighter $\left(\mathrm{M}^{\prime}=4-5\right)$, and shows more undulating veining (Fig. 5a).

$40 \mathrm{~g} 2$ is cut, in both exposures, by a lighter granite (at $~ 35 \mathrm{~m}$ in the lower exposure; Fig. 5e) which, in the upper exposure, constitutes a thicker body ( $\sim \mathrm{m})$ and has a more evident aplitepegmatite structure; this intrusive body was named $40 \mathrm{g3}$. A close examination of the contact shows the vein material from the gray granite entering the light granite body (Fig. 5f), suggesting that it could have formed by drainage of the veins. In fact, locally within the gray granite some larger veins filled with coarse-grained leucogranite were clearly formed this way.

In the upper exposure two thin layers $(5-20 \mathrm{~cm})$ of darker gray granite (sample NP40AJ; IC 10), both flanked by a coarse leucogranite similar to that forming the veins (Fig. 5b) appear within $40 \mathrm{~g} 2$ north the $40 \mathrm{~g} 3$ intrusive body.

The beginning and the end of both exposures are made up of heterogeneous garnet leucogranites with average $M^{\prime} 3-5$, and were named $40 \mathrm{~g} 1$ e $40 \mathrm{~g} 4$, respectively. A hololeucocratic granite with aplitic texture, varying to pegmatite, predominates in both bodies (Fig. 5c). A common feature in both is the presence of layering, defined by the intercalation of granites with varied $\mathrm{M}^{\prime}$ and grain size, showing several biotite-rich schlieren, especially in the lower exposure (Fig. $5 \mathrm{i})$. A big xenolith $(\sim 1 \mathrm{~m})$ of fine-grained garnetbiotite gneiss occurs next to the upper contact of $40 \mathrm{~g} 1$, and is totally surrounded by coarse-grained to pegmatitic granite.

The contact between $\mathbf{4 0 g 1}$ and $40 \mathrm{~g} 2$ is subconcordant, but the relationships observed suggest that $40 \mathrm{~g} 1$ intruded later. In the lower exposure, the pegmatite surrounding the xenolith has irregular contacts, appearing to locally intrude the gray granite (Fig. 5d). In the upper exposure, the veined gray granite is seen to be truncated by the aplite-pegmatite.

The contact between $40 \mathrm{~g} 4$ and $40 \mathrm{~g} 2$ is more complex, but also interpreted as indicative that the leucogranite $(\mathbf{4 0 g 4})$ is intrusive into the veined gray granite. A strong argument in favor of this relative age relationship is the presence of an irregular body, apparently a $\sim 3 \mathrm{~m}$ (maximum thickness) xenolith of gray granite within $40 \mathrm{~g} 4$, observed at the $60 \mathrm{~m}$ mark in the upper exposure (Fig. 3b).

In the lower exposure $(\sim 65 \mathrm{~m})$, both granites show strong structural variations next to the contact. In the veined gray granite, the veins are no longer irregular, and lay parallel to the contact in such a way that as this is approached the rock has the aspect of a gneiss (Fig. 5g). A possible interpretation for this feature is that the veined gray granite intrudes the leucogranite, and the more intense deformation towards the contact reflects compression against an already solidified mass. However, the first seven meters of the leucogranite preserve a delicate symmetrical layering that could have developped against a wall that seems to have been the gray granite. The layering is defined by a central portion of darkgray granite $(\sim 50 \mathrm{~cm})$ which is sandwiched by aplite with local schlieren and small pegmatite pockets $(\sim 150 \mathrm{~cm}$; cf. Fig. $5 \mathrm{~h})$ which in turn are flanked, next to the external contacts (the lower one with the gneissic gray granite), by pegmatite $(\sim 150 \mathrm{~cm})$. Our favored interpretation of this contact is that leucogranite $40 \mathrm{~g} 4$ is intrusive into $40 \mathrm{~g} 2$, and developped the layering against the wall of its lower contact. If this is true, the increment in deformation seeen in $40 \mathrm{~g} 2$ would be caused by the stress associated with the injection of $40 \mathrm{~g} 4$, implying that the gray granite still behaved plastically, and had already developped the venulation. In any case, it is evident that no significant time gap appears to exist between the intrusion of $40 \mathrm{~g} 2$ and $40 \mathrm{~g} 4$.

A late discordant 20-30 cm-wide biotite granite dike with significant syn-magmatic shearing, reminescent of those observed in outcrop NP74, is seen in the back of the lower cut (not shown in Fig. 4).

Asummary: the main types of anatectic granite Two contrasting 

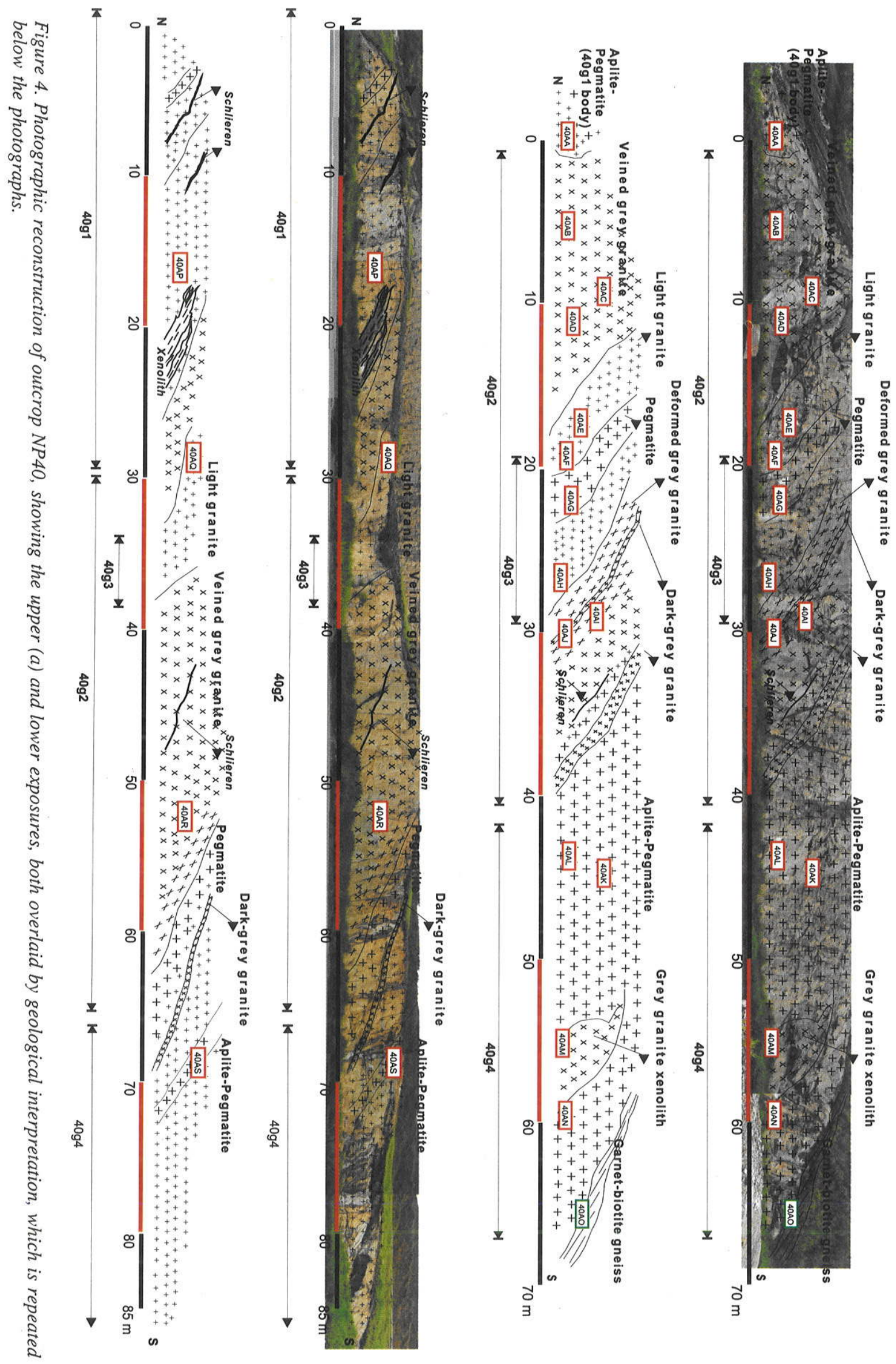

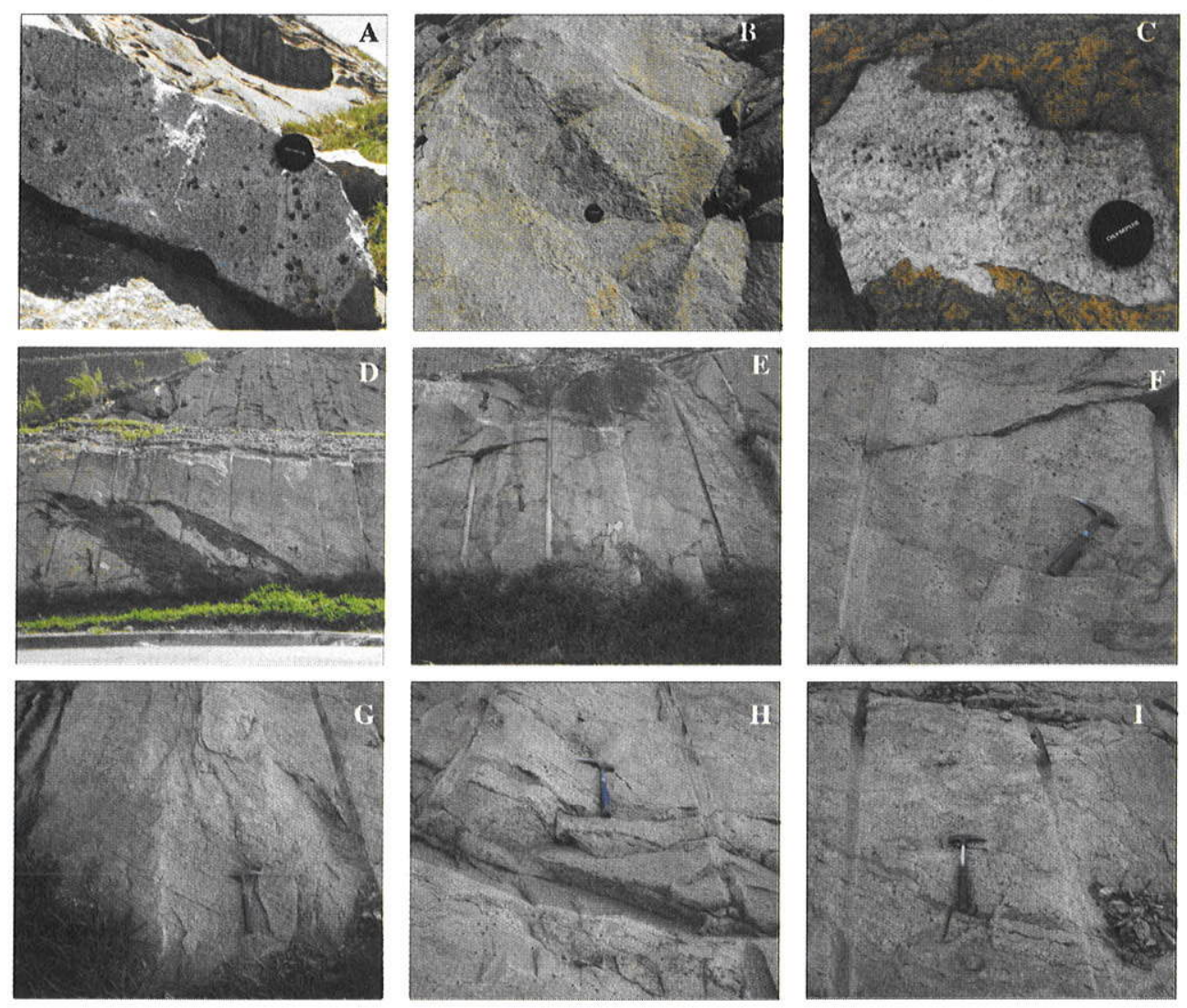

Figure 5. Field photographs of the Nazaré Paulista granite and country rocks in outcrop NP40. a) Detail of the structure of the veined gray garnet-biotite granite; note larger garnet crystals (partly replaced by biotite) in the light veins (upper exposure, at 10m); b) A $20 \mathrm{~cm}$-wide layer of dark gray granite sided by coarse leucogranite similar to the vein material within the veined gray granite (upper exposure, at $\sim 35 \mathrm{~m}$ ); c) Texture of the garnet leucogranite (lower exposure, 40g1, at $\sim 18 \mathrm{~m}$ ); note heterogeneous distribution of minerals, especially idiomorphic garnet); d) Upper contact of leucogranite 40g1, bearing a disrupted xenolith of calcic garnet-biotite gneiss. The irregular contact with the upper veined gray granite 40g2 is located immediately above the xenolith; $e$ ) The small body of leucogranite $40 \mathrm{~g} 3$ ( a 2 meter-wide subconcordant layer) within veined gray granite 40g2, seen in the lower exposure, at $33 \mathrm{~m} ; \mathrm{f}$ ) Detail of the contact between $40 \mathrm{~g} 3$ and $40 \mathrm{~g} 2$ : veins from the gray granite seem to continue into white granite 40g3. Same portion shown Fig. 5e; g) A detail of the upper contact of the veined gray granite 40g2, showing a foliated structure, the somewhat irregular contact, and a pegmatitic structure of the border of $40 \mathrm{~g} 4$ (lower exposure, $64 \mathrm{~m}$ ); $h$ ) Layer of dark gray granite at the center of a zoned body, surrounded by heretogeneous aplite rich in schlieren and small lenses of dark gray granite. Lower exposure, immediately above portion shown in Fig. $5 \mathrm{~g} ; \mathrm{i}$ ) Detail of the structure of the pegmatitic portion of $40 \mathrm{~g} 4$ at $\sim 70 \mathrm{~m}$ in the lower exposure. Note the large $K$-feldspar crystals (over $8 \mathrm{~cm}$-large) and abundant schlieren

petrographic facies are easily recognized in both exposures here studied in detail: veined gray garnet-biotite granite and garnet leucogranite.

A veined gray garnet-biotite granite makes up the northernmost and thickest body in outcrop NP74 (74g1), and consists of a medium-grained granite with $\mathrm{M}^{\prime}=5-7$ cut by usually rectilinear veins of coarser-grained biotite-poor garnet leucogranite. The vein material appears to correspond to residual melt that was released from the gray granite due to syn-magmatic deformation and along xenolith margins. The upper portion of $74 \mathrm{gl}$, rich in gneiss inclusions, is made up of garnet leucogranite interpreted as residual melt collected in the roof.

A significant portion of outcrop NP40 is also made up of veined gray garnet-biotite granite. Here however the granite is lighter (M' $=4-5$ ), and the veins have less rectilinear contours, suggesting seggregation under more plastic conditions.

The predominant rock forming the independent garnet leucogranite bodies is characterized by very low M' (2-3), lack or rarity of biotite, and idiomorphic crystals of pink garnet. In some cases it can be difficult to distinguish it from the veins in the gray garnet-biotite granite - both are hololeucocratic rocks that can show macroscopically similar aplitic to pegmatitic textures. In consequence, some doubt remains during field work in identifying the upper portion of $74 \mathrm{gl}$ as vein material collected in the roof or as a new body, perhaps related to $74 \mathrm{~g} 2$. It also can be speculated whether the small leucogranite body (40g3) intruding the center of the gray granite in outcrop NP40 corresponds to residual liquids from the latter or to a separate intrusion.

The main garnet leucogranite bodies are internally very heterogeneous, and differ from each other. The 40g1 and 40g4 bodies are similar in their inhomogeneity, and may be correlated: both are rich in biotite schlieren, and in are, by and most, of aplitepegmatite character. In outcrop 74, the zoned $74 \mathrm{~g} 3$ leucogranite body differ from the other leucogranite occurrences because of the presence of fibrolite films is some samples, and also because of the less calcic composition of its plagioclase. 
PETROGRAPHY Granites The main petrographic contrast between the different types of Nazaré Paulista granite is the abundance of biotite, which is absent or rare in the leucogranites, and a main constituent of the gray granites, in which it reaches 35 vol\%. Modally, most samples are monzogranite. However, the meter-sized aplite-pegmatite bodies as well as the aplite-pegmatite portions of some leucogranite bodies are heterogeneous: the pegmatite patches are rich in large K-feldspar crystals, whereas the surrounding aplite is enriched in plagioclase, some aplite hand samples being almost K-feldspar-free.

The texture of the granites is usually consertal, panxenomorphic, with a few crystal faces developped in mafic minerals (garnet and ocasionally biotite) and sometimes plagioclase. K-feldspar is a slightly perthitic microcline with welldeveloped chess-board twinning, and scarce inclusions of rounded quartz, biotite and accessory minerals. Plagioclase is slightly to not zoned, and has sometimes an ill-defined albite twinning; sericitization is normally discrete. An contents (measured on the electron microprobe by L. Martins; unpublished data) are $\sim 20$ in both gray granites and leucogranites in outcrop NP40. In outcrop NP74, they vary from $\sim A n 25$ in the 74 g1 gray granite to $\sim \mathrm{An} 20$ in the fibrolite-bearing leucogranite from the $\mathbf{7 4 g 3}$ body and to $\sim \mathrm{An} 30$ in leucogranite NP74U (from leucogranite body 74g2) and in pegmatite NP74Z (from pegmatite body ap3). Quartz is typically anhedral and often divided in subgrains with ragged contacts. Another typical occurrence is as rounded inclusions in both feldspars (more often in plagioclase) and in garnet.

Garnet is the main mafic mineral in all granite facies. It is often rich in inclusions of quartz and biotite, besides some accessory minerals as zircon and monazite. In the gray granite it is usually anhedral to subhedral, rich in quartz inclusions, and partly replaced by green biotite in the rims and along fractures (cf. Fig. 6a). Primary biotite inclusions are reddish-brown, but rarely preserved. In the leucogranites, particularly in the pegmatitic varieties, the garnet is often euhedral, and inclusion-poorer (Fig. 6b). However, a remarkable zoning is seen in crystals from a sample from the $74 \mathrm{~g} 3$ leucogranite body, where a core rich in small irregular quartz inclusion is mantled by a wide nearly inclusion-free rim (Fig. 6c).

Primary reddish-brown subhedral biotite crystals are typical of the gray granite (cf. Fig. 6d), and occur in smaller proportions in a few leucogranite bodies (e.g., portions of 74g3). Most leucogranites bear only secondary green biotite, often associated with reactions consuming garnet. Muscovite is present in some biotite-free leucogranites, and may form relatively large (mm-sized) crystals in some pegmatite varieties, but it is always xenomorphic, and no unequivocal evidence of a primary growth could be found.

Sillimanite occurs as few crystals, partly replaced by muscovite, in a leucogranite vein within the gray granite from $74 \mathrm{gl}$. Thin bundles of white fibrolite are seen parallel to leucogranite foliation (marked by the alignment of scarce small biotite crytals) in a portion of the $74 \mathrm{~g} 3$ leucogranite body. The microscopic observation shows these planes to correspond to strain surfaces that surround deformed feldspar crystals and locally cut xenomorphic quartz and feldspar grains (Fig. 6e). In some samples the fibrolite is surrounded or totally replaced by small muscovite flakes.

The main accessory minerals are ilmenite, zircon and monazite. In most samples apatite is nearly absent; xenomorphic rutile is sometimes associated with biotite in some gray granite samples. Zircon and monazite may occur as inclusions in all major felsic and mafic minerals and also in the contacts between quartz and feldspar grains (e.g., Fig. 6f). Zircon crystals are short and may have wellterminated pyramidal faces. Monazite is present in all granite varieties, but is more abundant in the gray granite and associated leucogranite veins, where small grains are common as inclusions in microcline.

Metamorphic rocks The metamorphic rocks found in both outcrops are dominantly migmatitic garnet-biotite gneisses with "granitic" composition. The main variations are: (1) sillimanite, always in small proportion ( $<1 \%$ vol.), appears in some samples from the beginning (NW extremity) and second half of outcrop NP74 (samples NP74A/ NP74E and NP74AB, respectively); (2) garnet-free biotite gneisses are the predominant rock-type in the middle portion of outcrop NP74, where they are commonly associated with small calc-silicate and/or amphibolite boudins, and are occasionally calcium-rich, as evidenced by the plagioclase and garnet compositions (e.g., samples NP74V, NP74Y); (3) the plagioclase/K-feldspar ratio may increase in some samples, especially in the garnet-free biotite gneisses, some of which have "tonalitic" compositions.

All rocks have a characteristic granoblastic texture in the "mesosome" portions; $\mathrm{mm}$ - to $\mathrm{cm}$-sized leucosomes, when present, have allotriomorphic to granoblastic textures, and are only occasionally surrounded by a biotite-rich melanosome. The leucosomes are modally diverse, but two main types, both garnetbearing, can be recognized on the basis of the $\mathrm{K}$ - feldspar abundance: (1) monzogranitic to syenogranitic leucosomes reminescent of the intrusive garnet leucogranites and (2) quartzrich "trondhjemitic" leucossomes, that locally appear to be related to an older, possibly non-magmatic event.

Plagioclase compositions are slightly more calcic than in associated granites ( An30-40 in typical garnet-biotite gneisses; up to An70 in biotite gneisses associated with calc-silicate boudins). Although not as common as in the Nazaré Paulista granites, round quartz inclusions are seen in some plagioclase and K-feldspar crystals. Slightly perthitic microcline has chess-board twinning and quartz shows usually undulous extinction.

Biotite, the most abundant mafic mineral (5-15 vol\%), is pleochroic in shades of brown, and has frequent zircon and monazite inclusions which develop distinct pleochroic haloes. Sillimanite, when present, is associated with biotite, following the foliation planes of the gneisses.

As in the granites, garnet is often partly replaced by green biotite and chlorite in fractures. Garnet-consuming reactions are locally evidenced by symplectite intergrowths with biotite + quartz \pm plagioclase \pm sillimanite (Figs. $6 \mathrm{~g}, \mathrm{~h}$ ). The generation of plagioclase at the expenses of garnet may reflect decompression, which is also suggested by mantling of garnet by plagioclase in amphibolite samples from nearby outcrops (Janasi, 1999a).

Accessory minerals in the garnet-biotite gneisses are ilmenite, zircon, monazite and apatite. Monazite is often associated with biotite (e.g., Fig. 6i) and may show sector zoning typical of metamorphic crystals in backscattered electron images. Apatite is usually very subordinate, except in some biotite gneiss samples.

CONCLUSIONS The Nazaré Paulista granite is strongly heterogeneous, as would be expected from its anatectic origin, but the lack of a detailed scrutiny of the observed compositional variation has led over the years to some confusion in the literature. The detailed study of the two best exposures available reveals that they are heterogeneous even at the outcrop scale, and occur 

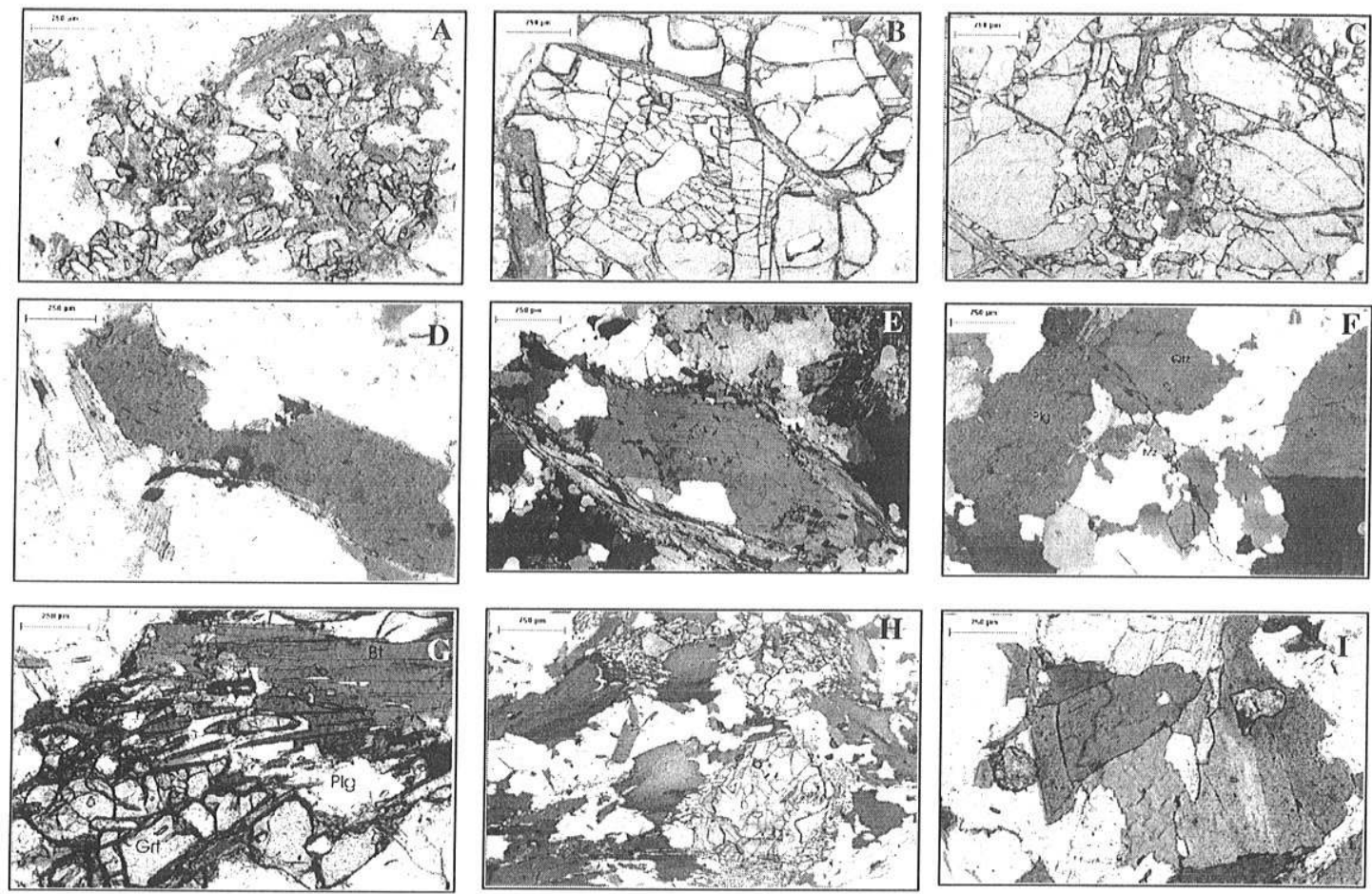

Figure 6 - Photomicrographs of the Nazaré Paulista granite and country rocks in outcropos NP74 and NP40. a) Poikilitic garnet rich in quartz inclusions and partly replaced by biotite; typical feature of the gray granites of both outcrops (sample NP4OAB); $b$ ) Subidiomorphic garnet with quartz inclusions (mostly at the core) and secondary green biotite along fractures (sample NP74U; $74 g 2$ body); c) Zoned subidiomorphic garnet with a core rich in small quartz inclusions; biotite in fractures and in the core seems to be mostly secondary (sample NP74AD; $74 \mathrm{~g} 3$ body); d) Primary subidiomorphic biotite with a monazite inclusion developping a wide pleochroic haloe (gray granite NP40AJ; 40g2 body); e) Secondary sillimanite (fibrolite) along strain surfaces surrounding a plagioclase crystal (sample NP74AD; crossed polarizors; 74g3 leucogranite body); f) Large monazite crystal in the contact between quartz (divided in subgrains) and plagioclase (sample NP74Z; crossed polarizors; pegmatite 74p3); g) Secondary plagioclase intergrown with biotite, apparently produced by a decompression reaction; border of a garnet crystal (sample NP74A; NW extremity of outcrop NP74); h) Symplectites with quartz, plagioclase, biotite and locally sillimanite rimming garnet crystals in Kfs-Pl-Grt-Bt gneiss NP74AB; i) Monazite crystals associated with biotite in Kfs-Pl-Grt-Bt gneiss NP74AB.

as several discrete subconcordant bodies with thicknesses not exceeding $50 \mathrm{~m}$.

Two main petrographic types of "Nazaré Paulista-type granites" are easily distinguished in the field: veined gray garnet-biotite granite and garnet leucogranite. Both are abundant in the two outcrops detailed here, and have wide regional distribution. Pinkish varieties of both types are found in nearby outcrops, especially northwest of outcrop NP74 (Fig. 1), but the color change appears to reflect secondary processes.

The gray garnet-biotite granite has a non-minimum melt composition, and as such was capable of generating a residue that was locally collected as a dense net of veins, probably as a reflection of syn-magmatic deformation. This residual melt crystallized as a coarse-grained (pegmatitic in some large pockets) garnet leucogranite that also was collected around gneiss inclusions and probably in the roof of some intrusions.

Garnet leucogranite forms also several independent, strongly heterogeneous bodies showing abundant aplite-pegmatite patches, magmatic banding and biotite-rich schlieren. Biotite is often absent in these rocks, or it occurs as very small matrix crystals. Muscovite and fibrolite may occur; the latter is apparently secondary, as thin films along the foliation in a portion of the $74 \mathrm{~g} 3$ body. Microscopic petrography may help distinguish these garnet leucogranites from those associated with the gray granites, as the latter usually have abundant monazite and may show some nonidiomorphic, inclusion-rich garnet crystals.

All Nazaré Paulista-type granite bodies are intrusive into the regional migmatitic paragneisses; they occur invariably as tabular bodies concordant with the gneiss layering, and only locally are seen to truncate their foliation. Relative age relationships among the different granite bodies were only established in outcrop NP40, where they appear in contact. Here, the garnet leucogranites appearing in both ends of the outcrop are interpreted to intrude the veined gray biotite-garnet granite when the latter had still a plastic behavior.

The observation, implying that both facies intruded contemporaneously, does not imply however that a similar relationship exists in other outcrops. As pointed out before, the available geochronological data, although still needing refinement, may imply that at least some granites from outcrop NP74 are up to 15 Myr younger than the $625 \mathrm{Ma}$ age obtained by Janasi (1999a,b) for the NP40 gray granite. The necessity to accurately date the different pulses of apparently simple crustal granites was recently highlighted by the recognition that the Manaslu granite in Himalaya was built up in two different pulses of magma generation separated by $4 \mathrm{Myr}$ (Harrison et al., 1999), possibly under different tectonic 
regimes and melting conditions (Knesel \& Davidson, 2002).

The identification of features indicative of syn-magmatic extension in outcrop NP74 is significant, as it offers a favourable scenario for magma migration and possibly also for magma generation (by decompression melting), perhaps similar to that recognized in recent studies for the Himalaya leucogranites (Scaillet et al., 1995; Patiño-Douce \& Harris, 1998). Textures indicative of decompression observed in some rocks from Nazaré Paulista, such as plagioclase-bearing coronas around garnet crystals in gneisses and amphibolites (e.g., Janasi, 1999a) are consistent with an extensional regime late in the metamorphic evolution of the region. If it is confirmed that the "Nazaré Paulista"-type granites were generated over a relatively large time range, however, it is possible that they resulted from varied tectonic regimes, whose structural and geochemical imprints in these granites are still to be clearly identified.

Acknowledgements Our research on the Nazaré Paulista granite was financed by Fapesp (00/02509-8). We thank Dr. Allen Fetter who helped us in our first detailed approach to outcrop NP74, and gave us access to his unpublished monazite data on a migmatite from this outcrop. Dr. Peter C. Hackspacher shared with us some thoughts on the tectonic meaning of the Nazaré Paulista granite, and drew our attention to some extensional structures in outcrop NP74. We also acknowledge the contributions from our Igneous Petrology students, as well as our colleagues Francisco R. Alves and Excelso Ruberti, who helped us test our hypothesis (not necessarily agreeing with them) on the relationships between rocks and their meaning, again in outcrop NP74. We also thank the two anonymous RBG reviewers for their suggestions.

\section{Referências}

Artur A.C., Wernick E., Hormann P.K., Weber-Diebenfach K. 1993. Associações plutônicas do Complexo Granitóide Socorro (Estados de São Paulo e Minas Gerais, Brasil). Rev. Bras. Geoc., 23:265-273.

Campos Neto M.C. 2000. Orogenic systems from Southwestern Gondwana: An approach to Brasiliano-Pan-African cycle and orogenic collage in Southeastern Brazil. In: U.G. Cordani, E.J. Milani, A. Thomaz Filho and D.A. Campos (eds.): Tectonic Evolution of South America. 31 st Intern. Geol. Congr., Rio de Janeiro, pp. 335-365.

Campos Neto M.C. \& Caby R. 1999. Neoproterozoic high-pressure metamorphism a ${ }^{\text {nd }}$ tectonic constraint from nappe system south of the São Francisco craton, southeast Brazil. Prec. Res., 97:3-26.

Campos Neto M.C. \& Caby R. 2000. Lower crust extrusion and terrane accretion in the Neoproterozoic nappes of southeast Brazil. Tectonics, 19:669-687.

Campos Neto M.C., Basei M.A.S., Artur A.C., Silva M.E., Machado R., Dias Neto C.M., Fragoso-Cesar A.R. 1983. Geologia das Folhas Piracaia e Igaratá. In: 1a Jornada sobre a Carta Geológica do Estado de São Paulo em 1:50.000. PRÓ-MINÉRIO, São Paulo, pp. 61-78.

Freitas F.C. 2000. Geotermobarometria e evolução metamórfica das rochas granulíticas da região de Socorro-SP. Dissertação de Mestrado, Instituto de Geociências, Universidade de São Paulo, 175 p.

Harrison T.M., Grove M., McKeegan K.D., Coath C.D., Lovera O.N., Le Fort P., 1999. Origin and episodic emplacement of the Manaslu intrusive complex, Central Himalaya. J. Petrol., 40:3-19.

Janasi V.A. 1986. Geologia e petrologia do maciço monzodioríticomonzonítico de Piracaia-SP. Dissertação de Mestrado, Instituto de Gseociências, Universidade de São Paulo, 281 p.

Janasi V.A. 1997. Crustal anatexis and granite genesis in the SocorroGuaxupé Thrust Nappe, southeastern Brazil: some constraints from elemental geochemistry. Rev. Bras. Geoc., 27:139-150.

Janasi V.A. 1999a. Petrogênese de granitos crustais na Nappe de Empurrão Socorro-Guaxupé (SP-MG): uma contribuição da geoquímica elemental e isotópica. Tese de Livre-Docência, Instituto de Geociências, Universidade de São Paulo, 304 p.

Janasi V.A. 1999b. A idade dos granitos Nazaré Paulista e Pinhal, e implicações para o metamorfismo da Nappe Socorro-Guaxupé (SPMG). In: SBG, Simp. Geol. Sudeste, 6, São Pedro, SP. Boletim de Resumos p. 7.

Janasi V.A. \& Ulbrich H.H.G.J. 1991. Late Proterozoic granitoid magmatism in the State of São Paulo, southeastern Brazil. Prec. Res., 51:351-374.

Knesel K.M. \& Davidson J.P. 2002. Insights into collisional magmatism from isotopic fingerprints of melting reactions. Science, 296:22042206.

Melhem M.M. 1995. Geologia e petrologia das rochas granitóides do maciço Atibaia e adjacências, SP. Dissertação de Mestrado, Instituto de Geociências, Universidade de São Paulo, 117 .

Oliveira M.A.F., Morales N., Fúlfaro V.J., Campos E.G. 1985. Projeto Atibaia, 1:50.000. Relatório Final, UNESP/PRÓ-MINÉRIO, v. 1, $117 \mathrm{p}$.

Patiño-Douce A.E. \& Harris N. 1998. Experimental constraints on Himalayan anatexis. J. Petrol, 39:689-710.

Ragatky D. 1998. Contribuicão à geoquímica e geocronologia do Domínio São Roque e da nappe de Empurrão Socorro-Guaxupé na região de Igaratá e Piracaia, SP. Tese de Doutorado, Instituto de Geociencias, USP, $131 \mathrm{p}$.

Scaillet B., Pêcher A., Rochette P., Champenois M. 1995. The Gangotri granite (Garhwal Himalaya): Laccolithic emplacement in an extending collisional belt. J. Geoph. Res., 100 (B1):585-607.

Tassinari C.C.G. 1988. As idades das rochas e dos eventos metamórficos da porção sudeste do Estado de São Paulo e sua evolução crustal. Tese de Doutoramento, Instituto de Geociências, Universidade de São Paulo, 236 p.

Ulbrich H.H.G.J., Vlach S.R.F., Janasi V.A. 2001. O mapeamento faciológico em rochas ígneas plutônicas. Rev. Bras. Geoc., 31:163172.

Vasconcellos A.C.B.C., Harris N.B.W., Tindle A.G. 1991. The relationship between metamorphism and tectonics: evidence from the SocorroGuaxupé thrust nappe, southeastern Brazil. In: P. Tuisku, K. Laajoki (eds.) Metamorphism, Deformation and Structure of the Crust Abstracts. Oulu, Finland. Res Terrae, Sér. A, No. 5, p. 86.

Wernick E., Weber-Diefenbach K., Correia P.R. 1987. O granitóide Nazaré Paulista: dados petrográficos, químicos e de tipologia do zircão. In: SBG,Simp. Reg. Geol., 6, Rio Claro-SP. Atas, SBG-NSP, 1: 123-134.

Manuscrito A 1499 Recebido em 13 de abril de 2004 Revisão dos autores em 25 de novembro de 2004 Revisão aceita em 05 de dezembro de 2004 